\title{
$\begin{array}{llllllllll}A & R & T & \text { I } & C & L & E\end{array}$
}

\section{The Rise and Fall of Finance and the End of the Society of Organizations}

by Gerald F. Davis

\section{Executive Overview}

Large corporations were a dominant force in American society for generations through their employment practices, expansion choices, and community connections. As the United States has shifted to a postindustrial economy, however, finance has increasingly taken center stage. This article documents shifts in corporate employment, institutional investment, corporate organization, financial services, governments, and household ties to financial markets over the past three decades. I argue that all these shifts can be seen as part of an interconnected movement toward a finance-centered economy, and that the recent economic downturn can be viewed as one outcome of this broader movement.

$\mathrm{T}$ he global economic downturn that closed the first decade of the 21st century revealed the centrality of finance to American society. Problems with arcane securities traded by obscure financial institutions rapidly spun out of control, potentially putting global capitalism itself at risk. Like a loose thread that manages to unweave an entire sweater, the mortgage crisis evolved into a credit crisis and ultimately into an economic crisis that is rivaling the Great Depression of the 1930s. The economic crisis in turn has forced us to grapple with the fact that the United States is now a fully postindustrial economy. By March 2009, more Americans were unemployed than were employed in manufacturing, and all signs pointed to further displacement in the goods-producing sector.

The disappearance of manufacturing employment has corresponded to another change: large corporations have lost their place as the central

This article is largely based on my book Managed by the Markets: How Finance Reshaped America. Oxford, U.K.: Oxford University Press, 2009. I thank Garry Bruton and two anonymous reviewers for wise suggestions for improving the argument, and Lynn Selhat for expert editing. pillars of American social structure. For most of the 20th century, social organization in the United States orbited around the large corporation like moons around a planet. Understanding the workings of the corporation was the key to understanding our "society of organizations." Peter Drucker described this vision of society in 1949: "In the industrial enterprise the structure which actually underlies all our society can be seen.... It symbolizes the new organizing principle of an industrial society in the purest and clearest form, just as the perfect crystal in a mineralogical museum presents in perfect form the organizing principle which the mineral always tends to follow in whatever shape it is found" (Drucker, 1949, pp. 28-29). But today, as this paper argues, corporations are no longer the organizing principle of U.S. society. As a result, we are left to pick up the pieces of an economic crisis saddled with institutions and a conceptual model of society suited for an era that has passed.

In this article, I describe how we got here and suggest some of the implications for management

Gerald F. Davis (gfdavis@umich.edu) is the Wilbur K. Pierpont Collegiate Professor of Management at the Ross School of Business, the University of Michigan. 
scholarship. The argument has many moving parts, and each component could be (and has been) the subject of a book-length treatment. The risk of such a 30,000-foot view is that important details are left out. But the parts are interlocking-it is more like a novel than a short story collection. In short, I argue that the shift from an industrial to a postindustrial economy in the United States was decisively shaped by finance, and that the ascendance of finance effectively ended the reign of the society of organizations. Societies of organizations still exist outside the United States, particularly in East Asia. But I argue here that events unfolded in the United States to favor finance at the expense of organizations.

The argument is as follows. As manufacturing employment gave way to services and the largest employers shifted from firms such as GM to those such as Wal-Mart, the nature of the employment relation changed: The long-term mutual obligations of old were replaced by expectations of more temporary attachments. Changing employment ties were facilitated by the advent of relatively portable defined-contribution pensions, which provided a vast source of new investment for mutual funds-particularly the half-dozen largest fund families that captured the bulk of these inflows. The growth of pension investment helped concentrate ownership in the hands of institutional investors, which abetted an overriding corporate focus on shareholder value as the ultimate measure of corporate and managerial performance. This orientation toward share price led corporations to restructure toward a flexible original equipment manufacturer (OEM) or network model of corporate organization, which further encouraged more tentative employment ties.

At the same time, securitization (turning loans and other assets into tradable bonds) changed the nature of banking and finance, allowing more kinds of assets to be traded on markets and opening new avenues for households to participate in financial markets. Households increasingly became both investors (through pension plans and retail mutual funds) and issuers (through securitized home mortgages, credit card debt, student loans, and insurance payoffs). As ties to particular corporate employers waned, ties to financial mar- kets waxed. The old model of the organization man was increasingly replaced by a model of the investor trading in various species of capital (financial, human, social). This model, it is safe to say, has failed, but management scholars and practitioners are yet to fully adapt our theories or policies as business moves to its new incarnation.

\section{The Arrival of Postindustrial Society}

n 1973 sociologist Daniel Bell published a book titled The Coming of Post-Industrial Society: A Venture in Social Forecasting to speculate on the implications of broad trends in economy and society, primarily in the United States. One of the most visible trends - and the source of the book's title—was "postindustrialism," defined most simply as a situation in which "the majority of the labor force is no longer engaged in agriculture or manufacturing but in services" (Bell, 1973, p. 15). At the time he wrote the book, the United States was the only "postindustrial" society by this criterion, with about $60 \%$ of its labor force in services; the vast majority of other countries' economies were still dependent primarily on agriculture and natural resource extraction.

Today the transition to postindustrialism is nearly complete in the United States, as agriculture and manufacturing account for less than $10 \%$ of the total labor force (and that percentage continues to fall). Figure 1 shows the relative proportions of the nonfarm labor force engaged in retail and manufacturing and documents a continuous decline in manufacturing's share since the Second World War, and an absolute decline in manufacturing employment since the late 1970s. The 21st century has seen an acceleration in this trend: Between December 2000 and May 2009, the United States lost 5.25 million manufacturing jobs, or more than $30 \% .{ }^{1}$ Troubling signs in durable goods industries - particularly auto manufacturing, where two of the three U.S.-based manufacturers had fallen into bankruptcy-indicated that there was more bad news to come.

\footnotetext{
${ }^{1}$ Labor statistics by industry and sector are available from the Bureau of Labor Statistics, http://data.bls.gov/PDQ/outside.jsp?survey=ce and http://www.bls.gov/news.release/ecopro.t01.htm. News releases on unemployment are posted at http://www.bls.gov.
} 


\section{Figure 1}

Percentage of U.S. Nonfarm Workforce in Manufacturing and Retail, 1939-2008

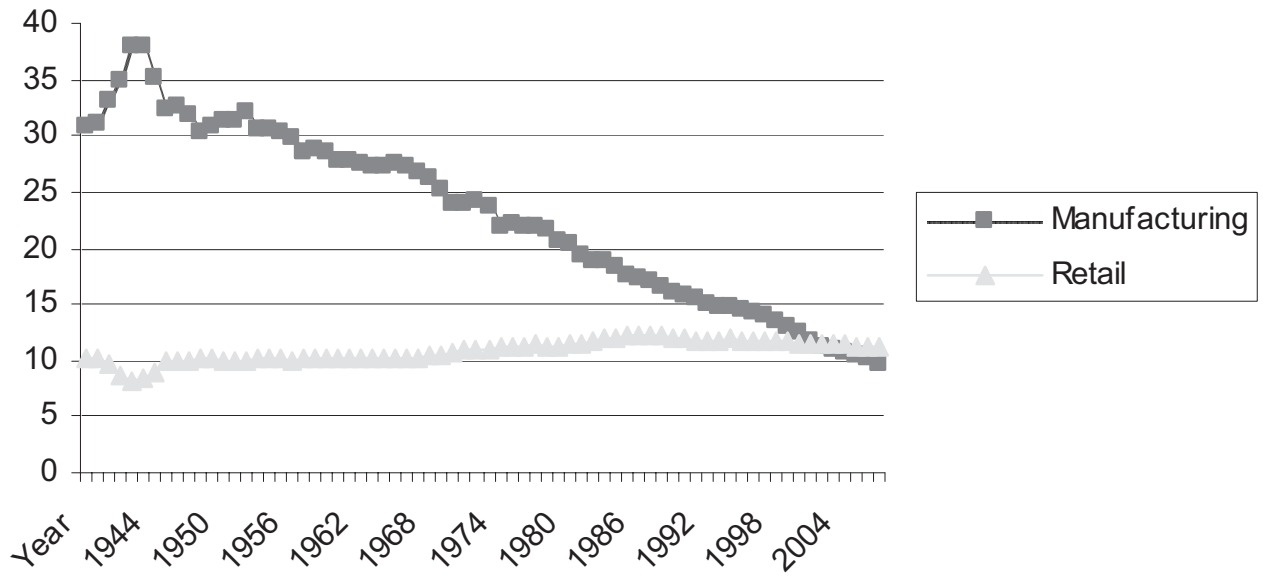

Source: Bureau of Labor Statistics.

The loss of jobs in manufacturing prior to the downturn was often attributed to offshoring-the use of foreign contractors for production. There is clearly a great deal of offshoring, as the neardisappearance of industries such as textiles demonstrates. But a more fundamental source of lost manufacturing employment is expanded productivity. The United States still leads the world in manufacturing value added, with a global share of about $22 \%$. Japan is number two, with $14 \%$, and China trails with $11 \%$ (Hilsenrath \& Buckman, 2003). ${ }^{2}$ But the manufacturing sector's productivity is such that relatively few employees are required. This became evident during the downturn, when many American manufacturers found that it was impossible to find anyone to lay off because their remaining employees accounted for such high revenues. The Wall Street Journal in March 2009 quoted the CEO of Parker Hannifin ${ }^{3}$ as saying: "Because of productivity gains, every one of my people carries more dollars in sales today [i.e., $\$ 200,000$ per worker compared to $\$ 125,000$ in 2000]. If I need to cut back, I have to cut back fewer people to achieve the same goal" (Aeppel \& Lahart, 2009). Like modern industrial agriculture, with which a comparatively minuscule labor force

\footnotetext{
${ }^{2}$ Time series data on manufacturing value added by country is available at http://www.nationmaster.com/graph/ind_man_val_add_cur_usmanufacturing-value-added-current-us.

${ }^{3}$ Parker Hannifin is a manufacturer of motion and control technologies and systems, providing precision-engineered solutions for a wide variety of mobile, industrial, and aerospace markets.
}

can produce all the food a nation needs, ITenabled manufacturing requires only a minimal workforce. Postindustrialism, in other words, is less about moving jobs around the globe than about the inevitable effects of productivity improvements in a capitalist economy (cf. Kollmeyer, 2009).

One of the most visible manifestations of the new postindustrial American economy is the change in the composition of the largest corporate employers. Table 1 lists the 10 largest U.S. employers in 1960,1980, and 2009. In the two earlier periods, the list was dominated by a handful of large manufacturers, AT\&T, and Sears. Many of these companies dated their origins to the wave of industrialization and consolidation around the

\section{Table 1}

10 Largest U.S. Corporate Employers, 1960-2009

\begin{tabular}{|l|l|l|}
\hline \multicolumn{1}{|c|}{1960} & 1980 & \multicolumn{1}{c|}{2009} \\
\hline GM & AT\&T & Wal-Mart \\
\hline AT\&T & GM & Target \\
\hline Ford & Ford & UPS \\
\hline GE & GE & Kroger \\
\hline U.S. Steel & Sears & Sears Holdings \\
\hline Sears & IBM & AT\&T (SBC) \\
\hline A\&P & IT & Home Depot \\
\hline Exxon & Kmart & Walgreens \\
\hline Bethlehem Steel & Mobil & Verizon \\
\hline IT & GTE & Supervalu \\
\hline
\end{tabular}

Source: Compustat for 1960 and 1980; Form 10-K for 2009. 
turn of the 20th century. The typical workplace of these firms was both large and interconnected. Ford's famous River Rouge plant employed 75,000 workers when it was completed in 1927, and grew from there. A visitor to the Rouge in the late 1960s could have followed a shipment of iron ore from one end of the complex through its processing into steel and ultimately into the body of a Ford Mustang that rolled off the assembly line at the other end.

Large-scale workplaces facilitated labor organization, and for decades the largest firms were in the vanguard of progressive human resource management practices, often at the behest of unions or in an effort to forestall them. During the Second World War, many large manufacturers attempted to skirt wage restrictions by offering expansive benefits packages to lure scarce labor. These "academy employers" set the standard for other employers with systems of internal labor markets, job security, health insurance, and retirement benefits, and thus had a substantial influence on the nature of the employment relation in the United States (Cappelli, 1999; Jacoby, 1997).

Today, the largest employers are overwhelmingly in retail, where wages, benefits, and tenures are substantially lower. The shift has been stark: By 2009, Wal-Mart employed about as many Americans (1.4 million) as the 20 largest U.S. manufacturers combined, and 9 of the 12 largest employers were retail chains. ${ }^{4}$ The wage and tenure differences between the old guard and the new are striking. On average, production workers in motor vehicle manufacturing earned $\$ 27.43$ per

\footnotetext{
${ }^{4}$ I estimated the largest manufacturing employers using firms' annual 10-K statements, accessed at http://www.sec.gov. "Manufacturers" were those deriving most of their revenues from manufacturing, an increasingly uncertain determination. IBM would have been classified as a manufacturer when most of its sales were in hardware such as mainframes, but it now derives the large majority of its revenues from global services and software. GE derives roughly half its revenues from GE Capital Finance $36.7 \%$ in 2008) and NBC Universal (9.3\%). Moreover, some firms report U.S. employment directly; others (such as GM and Ford) report North American employment - presumably including Canada and Mexico—while others do not break out employment but do report revenues by geographic segment, allowing a rough approximation. Given these caveats, estimated U.S./North American employment for the 10 largest manufacturers at year end 2008 are (in thousands) Boeing (162), Lockheed Martin (131), Northrop Grumman (124), GM (116), Tyson (99), General Dynamics (92), Ford (89), United Technologies (78), Emerson Electric (70), and Pepsico (64). For comparison purposes, grocery chain Supervalu, number 10 on the list of largest employers, had 192,000 workers in 2008.
}

hour in February 2009, while those working in general merchandise retailing made $\$ 10.78$. The Current Population Survey for January 2004 reported that the median employee in auto manufacturing was 44 and had been with his current employer for 8 years, while the median worker in electrical equipment and appliance manufacturing was 46 and had 10 years' tenure. Retail employees, in contrast, averaged three years' tenure with their current employer, even though they were 38 years old on average (see Davis, 2009, p. 201 ff.).

In a retail economy, workplaces are both smaller and less overtly interdependent than in mass-production manufacturing. Even Wal-Mart Supercenters, perhaps the largest organisms in the retail ecology, typically employ fewer than 350 people. Yet like the auto assembly line, retailers are susceptible to a postindustrial form of Taylorism thanks to the pervasive use of information and communication technologies (ICTs) such as "workforce management" software systems. These systems automate the time-and-motion studies of Frederick Taylor's Scientific Management, tracking the minute-by-minute productivity of sales associates and monitoring how many milliseconds it takes cashiers to scan each SKU in a grocery cart. Managers in remote locations can monitor, compare, and discipline every salesperson in a retail chain with the aid of real-time standardized comparison charts and discreet wireless headsets. Scheduling can be automated to reward the productive with prime hours and punish the weak with less-desirable opening and closing times (O'Connell, 2008). With less need for direct supervision and middle management, such retail outlets might optimistically be called a "flat" hierarchy. But the flip side of a flat hierarchy is limited room for advancement beyond the sales floor.

Large-scale employers that provided job security, career mobility through job ladders, and generous health and retirement benefits seem to have been artifacts of the corporate-industrial age in the United States. Many of the so-called academy employers have explicitly renounced the former practices that tied employees to their firms, through freezing company pensions and phasing out retiree health benefits. General Motors, for 
instance, notified its white-collar retirees in July 2008 that in the new year they and their dependents would no longer be covered by GM-financed private health insurance because it had become too costly. Instead, they would be compensated with a $\$ 300$ increase in their monthly pension checks (Bunkley, 2008).

GM was simply following the path blazed by some of its peers. GE's former CEO Jack Welch earned the nickname "Neutron Jack" in the early 1980s by shrinking GE's payroll of 400,000 by more than one-quarter. In 2001, Welch summarized the new employment compact he had helped usher in for a group of Harvard MBA students: "If there's one thing you'll learn-and dot-coms have learned it in the last year-is no one can guarantee lifetime employment.... You can give lifetime employability by training people, by making them adaptable, making them mobile to go other places to do other things. But you can't guarantee lifetime employment" (Lagace, 2001, p. 1). And if corporate employers have abandoned the vestiges of long-term employment as anachronistic, so too have employees. Contemporary workers are too sophisticated to invest in developing firm-specific skills for a company that might go from good to great to liquidation, as Circuit City did. In a service economy, it's best to keep one's skills sufficiently generic so that one is "mobile to go other places to do other things"-say, selling sweaters instead of cell phones.

The result of the shift from manufacturing to service, in short, has been a disaggregation of employment in which the attachments of workers to particular firms is more tenuous, expected tenures are shorter, and workplaces themselves are often on a smaller scale. The traditional rationale for maintaining long-term employment relations was in part to encourage the development of investments in firm-specific skills. Greater employee mobility thus goes hand in hand with lower firmspecific investments.

\section{The Rise of Institutional Investment}

T he disaggregation of employment that accompanied postindustrialism had another, less obvious effect, namely, the promotion of greater aggregation in corporate ownership by financial intermediaries. This happened through a change in pension financing that channeled a large portion of household savings into a very small number of mutual fund complexes, which ultimately ended up holding concentrated ownership positions in hundreds of U.S. corporations.

Most companies that provided pensions prior to the early 1980s did so through so-called "defined-benefit" plans that paid retirees benefits according to their tenure with the company. In a defined-benefit plan, the employer is responsible for creating an investment pool sufficient to fund the stream of pension income promised to its employees when they retire. Defined-benefit plans provided employees strong incentives to spend their careers with particular employers. With the advent of the 401(k) in the early 1980s, however, the large majority of employers that still provided pensions began a shift toward funding relatively portable plans in which employees and firms both contribute to an individually owned pension that can be rolled over if the employee changes jobs. These "defined-contribution" plans effectively transferred risk from employers to workers, who were now responsible for making sensible investment choices on their own behalf from among the options offered by their employer (see Cobb, 2008; Hacker, 2006). Although employers were motivated in part by cost considerations, the effect was to loosen the ties that bound employees to firms, further reinforcing the trends described in the previous section.

The growth in defined-contribution pension plans helped fuel the growth of the mutual fund industry. Those 401(k) plans most commonly invest in mutual funds. Some plans offer options other than mutual funds-Enron famously matched its employee contributions with Enron stock that employees were forbidden to shift to other investments- but mutual funds are perhaps the dominant destination for employee contributions. The mutual fund industry thus grew enormously during the 1980s and 1990s, both through $401(\mathrm{k}) \mathrm{s}$ and through retail investment, as households found mutual funds to offer better returns than other savings vehicles. The Investment Company Institute reported that there were 564 mutual funds in 1980, 3,079 in 1990, and 8,155 in 
2000. Assets under management increased from $\$ 135$ billion in 1980 to $\$ 12$ trillion in 2007. And where only $6 \%$ of households were invested in mutual funds in 1980, 45\% were in 2008. Inflows were particularly pronounced in the 1990s: According to author and historian Steve Fraser: "More was invested in institutional funds between 1991 and 1994 than in all the years since 1939" (Fraser, 2005, p. 583). The bull market and investment by households were mutually reinforcing during the subsequent decade, as retail investors are typically "momentum investors" (putting money into the stock market in the wake of price increases). By 2001, according to the Federal Reserve, $52 \%$ of households owned stock - the highest proportion in U.S. history-and most did so directly or indirectly through mutual funds. ${ }^{5}$

The broad spread of stock ownership among the American populace left some commentators rapturous about the new "democratization of ownership" and its potential benefits (e.g., Duca, 2001; Hall, 2000). An electorate attuned to the financial markets had incentives to become more economically literate and might be more readily persuaded by fiscal arguments that appealed to their interests as shareholders. But the democratization of ownership is clearly a representative democracy, channeled through intermediaries. Fewer than one in five households owned shares directly in companies in 2007, about the same rate as three decades earlier. Moreover, the value of the average family's portfolio in 2009 was under $\$ 23,000$ (see Bucks et al., 2009, p. A27). Stock ownership was broad but not deep among the American populace. The real significance of this movement was in its effect on the structure of corporate ownership.

The growth in the mutual fund industry was highly uneven. Although the number of funds and their assets under management grew in the aggregate, the biggest beneficiaries of the flood of new retail investment were the half-dozen or so well-

\footnotetext{
${ }^{5}$ Figures on mutual funds are from the 2009 Investment Company Institute Factbook, accessed at http://www.icifactbook.org/. Data from the Federal Reserve's triennial Survey of Consumer Finances, including household ownership data, and related publications are available at http:// www.federalreserve.gov/PUBS/oss/oss2/scfindex.html.
}

known fund complexes, which maintained nearly $40 \%$ of the industry's assets under management over the past two decades. As a result, a few fund families-Fidelity, Vanguard, and the American Funds in particular-grew to become the most prominent owners of corporate America. (They have since been joined by Barclay's through the enormous popularity of its iShares exchangetraded funds.) At any given time during the past 15 years, Fidelity was the largest shareholder of roughly 1 in 10 U.S. corporations. Because most of Fidelity's funds are actively managed and rely on the research of in-house analysts, Fidelity often ends up being the biggest shareholder of several competitors in the same industry. In early 2001, for instance, Fidelity's parent owned $6.9 \%$ of Wendy's International and $6.4 \%$ of McDonald's, where it was the largest single shareholder. And although not an "owner" in the traditional sense, Fidelity has the power to buy, sell, and vote shares, giving it great potential power in corporate governance (Davis, 2008).

Yet while corporate ownership has become more concentrated in the United States than at any time since perhaps the First World War, this has not resulted in a revival of the sort of finance capitalism that reigned a century ago, when J. P. Morgan's henchmen served as directors on dozens of boards of companies he had financed (Brandeis, 1914). If anything, mutual funds are remarkably passive in corporate governance, even though fund families routinely gather ownership blocks of over $10 \%$. The reasons for this are up for debate, but one is clear: The largest mutual funds are also among the largest providers of pension fund services to corporate employers, and Fidelity contracts for benefits outsourcing with hundreds of its portfolio firms. In a highly interconnected financial world, there are good reasons not to offend actual or potential clients with unseemly shareholder activism. ${ }^{6}$

\footnotetext{
${ }^{6}$ For a description of the growth in concentrated ownership by mutual funds and a comparison with early 20th-century finance capitalism in the United States, see Davis, 2008. The classic account of early 20th-century finance capitalism in the United States is found in Brandeis, 1914. For an analysis of conflicts of interest in proxy voting by mutual funds, see Davis and Kim, 2007.
} 


\section{Shareholder Value, Corporate Restructuring, and the "OEM Model"}

W hen corporate executives look out at their investors today, they don't see the dispersed widows and orphans of times past - they see a relative handful of financial institutions. Nearly three-quarters of the average Fortune 1000 corporation's shares were owned by institutional investors in 2005, with mutual funds making up the most concentrated block. Fidelity, one of the biggest fund families, held blocks of $10 \%$ or more in hundreds of corporations at the same time. The outcome of three decades of increased individual participation in financial markets, through mutual funds and $401(\mathrm{k}) \mathrm{s}$, has been a reconcentration of ownership in the hands of a few financial intermediaries. This was precisely the opposite of what had happened during the first wave of individual stock market participation in the 1920s, where the quadrupling of shareholders in a few short years had broadly dispersed ownership, creating the famous "separation of ownership and control."7

The rise of relatively concentrated institutional ownership has corresponded with an increased focus on share price as the most relevant measure of corporate performance. This is by now a familiar story, told in a number of books such as Michael Useem's (1996) Investor Capitalism. The cultural result is all around us. By the late 1990s, the financial news media were pervasive, financial analysts such as Mary Meeker and Henry Blodgett were household names, and firms faced high levels of scrutiny for their share price performance. It became difficult to walk through a public place, or to browse the Web, without being made aware of how the stock market was doing. Talking heads on CNN and the various financial news networks were inevitably accompanied by a stock ticker crawl at the bottom of the screen, so that CEOs (or even American presidents) were tethered to the market reactions to their every word. CEOs had personally compelling reasons to attend to their company's share prices, as executive compensation came to

\footnotetext{
${ }^{7}$ On patterns in household ownership during the early part of the 20th century, see Cox, 1963. The phrase "separation of ownership and control" is primarily associated with Berle and Means (1932).
}

be overwhelmingly paid in the currency of stock options during the 1990s.

By the end of the decade, any lingering doubt about the purpose of the corporation, or its commitment to various stakeholders, had been resolved. The corporation existed to create shareholder value; other commitments were means to that end. Mission statements posted on corporate websites in the late 1990s made this clear: "We exist to create value for our share owners on a long-term basis by building a business that enhances The Coca-Cola Company's trademarks." And "Sara Lee Corporation's mission is to build leadership brands in consumer packaged goods markets around the world. Our primary purpose is to create long-term stockholder value."

For manufacturers in particular, the relentless focus on share price promoted the spread of the network or "OEM model" of corporate organization. ${ }^{8}$ Ironically, the name "original equipment manufacturer" implies precisely the opposite of what it means in practice. Nike is a prototypical OEM: It focuses on the design and marketing of its products while leaving their production and distribution largely to others. Coca-Cola is another: Although an outsider might see its business as selling sugary carbonated beverages, the CocaCola Company itself is primarily in the brand management business, while manufacturing and distributing the product is done by dispersed bottlers. ${ }^{9}$ The value added by Nike or Coca-Cola is through intellectual property-brands, patents, advertising copy, distribution know-how. Nike and Coke, like pharmaceutical companies and universities, are in the ideas business.

Share price is both a consequence and a cause of corporate structure: a consequence because the market values firms with different structures differently, and a cause because executives adopt strategies and structures with an eye toward the expected market reaction. One of the best-documented regularities is the so-called "conglomerate

${ }^{8}$ What I here call the OEM model is akin to the network models described elsewhere, e.g., Scott and Davis, 2007. Sturgeon (2002) similarly described a "modular production network."

${ }^{9}$ The Coca-Cola Company does, however, own 35\% of Coca-Cola Enterprises, its largest bottler, responsible for $16 \%$ of Coca-Cola's global volume. 
discount," in which firms operating in more than one industry suffer lower market valuations than comparable focused firms. For a conglomerate, the stock market value of the whole is often worth much less than the sum of the parts if they were freestanding companies. Beatrice was an example: At the beginning of the 1980s, the company's portfolio of products included various branded foods (e.g., La Choy), Culligan plumbing equipment, Airstream travel trailers, Samsonite luggage, and dozens of others. Conglomerates offered a tempting target for outside raiders, who could make a quick profit by buying such chronically undervalued firms, splitting them up, and selling the parts off to buyers in related industries in the newly relaxed antitrust environment provided by the Reagan administration. As a result, about onethird of the 1980 Fortune 500 disappeared during the 1980s, largely due to bust-up takeovers that collectively redrew the American industrial map (Davis, Diekmann, \& Tinsley, 1994).

By the 1990s, corporate executives were intensely aware of the stock market consequences of diversifying outside of their "core competence," and this helped drive their restructurings. For instance, when Ford CEO Alex Trotman announced the firm's spinoff of its financial division Associates First Capital in 1997, he said: "We believe the market value of the Associates is neither fully nor consistently reflected in Ford's stock price. Because the market views Ford as an automotive company, it has not fully recognized or rewarded us for our diversification in nonautomotive financial services businesses" (Bradsher, 1997, p. D1). ITT's CEO announced a plan to split his venerable conglomerate into three freestanding parts (insurance, industrial products, and hotels and casinos) with this explanation: "We just think that having these three companies acting and operating and being evaluated in their own business environments will provide investors, analysts, and those who deploy debt a simpler, more clear way to evaluate us" (Strom, 1995, p. D1). The boundaries of the firm, in other words, were shaped less by considerations of transaction costs and asset specificity than by the cognitive capacities of Wall Street (cf. Zuckerman, 1999).

Over time, share price concerns drove more radical forms of restructuring. For example, "board stuffers" in electronics-generic manufacturers such as Flextronics and Solectron, capable of assembling and delivering virtually any electronic product from cell phones to servers-allowed high-tech versions of the Nike model across a wide variety of electronic products. A HewlettPackard vice president explained why it turned over its computer manufacturing and distribution to a board stuffer: "We own all of the intellectual property; we farm out all of the direct labor. We don't need to screw the motherboard into the metal box and attach the ribbon cable" for an HP-branded computer to be an HP (Hansell, 1998, p. 3:1). The rationale for restructuring ultimately turned on the idea that the stock market values intellectual property over tangible assets. CEO John Bryan of Sara Lee, maker of consumer brands such as Champion, Hanes, and Ball Park Franks, stated it plainly when he explained why his firm was divesting most of its manufacturing capability in order to focus on its core competence of brand management: "Wall Street can wipe you out. They are the rule-setters. They do have their fads, but to a large extent there is an evolution in how they judge companies, and they have decided to give premiums to companies that harbor the most profits for the least assets."

By now, cell phones, hot dogs, PCs, pet food, and pharmaceuticals are routinely produced by contractors, leaving OEM firms to manage the intellectual property behind these products-patents, brand names, trademarks, and research capabilities. For Sara Lee, as its CEO hinted, a production line was worth less than the advertising line "Gentlemen prefer Hanes." The consequences of the spread of the OEM model have occasionally been tragic. In 2007, thousands of dogs and cats in the U.S. fell ill when their food turned out to have been tainted with melamine, a cheap industrial filler that is chemically similar to protein. More than 100 competing brands, from Science Diet and Iams to Wal-Mart's Ol' Roy, turned out to be manufactured by the same vendor, Ontario's Menu Foods, which in turn relied on anonymous foreign suppliers for its "meat." A few months after that incident hundreds of humans were injured, and 81 killed, when batches of 
Baxter Healthcare's blood thinner heparin were discovered to be toxic. The drug was manufactured by a Chinese vendor that in turn relied on mom-and-pop suppliers for a key ingredient that appeared to be the source of the taint: pig intestines (see Davis, 2009, Chapter 5).

Thanks to two decades of restructuring driven by a quest for shareholder value, the global supply chains of contemporary corporations increasingly resemble the "nexus of contracts" described by the finance-based theory of the corporation (Jensen \& Meckling, 1976; for more on global supply chains, see Rivoli, 2005). One consequence of this widespread restructuring is that career ladders ain't what they used to be. Horatio Alger stories of ambitious young people from modest backgrounds working their way up from the mailroom to the CEO's office, always apocryphal, are even more unlikely now that the mailroom (and the food service, human resource department, IT department, and support staff) are all contracted out. Research suggests that young men entering the labor market in the 1980s and 1990s were much more likely to remain in "entry level" jobs 10 years later than were their predecessors in the late 1960s and early 1970s. It appears that for many, the career ladder had been replaced by the career Roach Motel as another unexpected consequence of the shareholder value movement (Applebaum et al., 2003; Bernhardt et al., 1999).

The trends I have described so far were mutually reinforcing. Changes in the largest employers corresponded to changes in pension financing toward defined-contribution plans that facilitated both the decline in career attachments to particular employers and increased participation in financial markets through mutual funds. The growth in institutional investor size and influence focused firms' attention onto the share price implications of their choices of strategy and structure and, enabled by information technology, firms increasingly adopted network forms that further weakened the bonds between workers and firms.

The increasing importance of finance, however, did not lead to the dominance of particular financial institutions. Consolidation in some parts of the financial services industry, particularly commercial banking, took place at the same time that banks were restructuring along lines similar to other corporations.

\section{Securitization and the Changing Nature of Banking}

inance itself has not been immune to the allure of the OEM model. In this case, it is traditional banking that has been transformed through the practice of "securitization"- that is, turning assets (such as loans on the balance sheet) into securities traded on markets. The traditional model of banking is fairly simple: Banks gather deposits from savers, who are paid interest, and lend it to borrowers, who pay it back at a higher rate of interest. In the movie It's a Wonderful Life, banker George Bailey explains this model to his anxious depositors, who are causing a run on the bank: "No, but you ... you're thinking of this place all wrong. As if I had the money back in a safe. The money's not here. Your money's in Joe's house . . right next to yours. And in the Kennedy house, and Mrs. Macklin's house, and a hundred others. Why, you're lending them the money to build, and then, they're going to pay it back to you as best they can. Now what are you going to do? Foreclose on them?"

The best-known form of securitization is mortgage-backed bonds, in which hundreds or thousands of mortgage loans are pooled together and then divided into bonds that, by the law of large numbers, have more predictable and "safer" returns. This practice allows banks to free up funds for additional lending and generally lowers the cost of taking out a mortgage. Rather than relying on a local bank and its depositors to fund their home purchase, buyers can access funds from dispersed investors around the world via mortgagebacked securities. A modern-day George Bailey might have a more difficult time explaining contemporary banking: "No, but you ... you're thinking of this place all wrong, as if I held your mortgage on my balance sheet. I sold your mortgage to Countrywide 10 minutes after we closed the deal, and they sold it along with 3,000 other mortgages to Merrill Lynch, which divided it into bonds that were bought by a Cayman Islands LLC, which bundled them together with other mort- 
gage-backed bonds into a collateralized debt obligation that Citigroup sold to a Norwegian pension fund. Now what are you going to do? Stop making your payments and force those Norwegian retirees to go back to work?"

Securitization turned expansive during the 1990s, driven by demand from institutional investors seeking outlets for their funds, supply from Wall Street banks that got paid by the transaction, and information technology that enabled the valuation of ever-more-exotic instruments. From home mortgages to auto loans to credit card receivables and corporate loans, almost anything with an income stream seemed to end up as a bond, and the bond market vastly outstripped the stock market in value. Innovations in assetbacked securities turned surprisingly postmodern. David Bowie received $\$ 55$ million in return for bonds backed by his future music royalties. J.G. Wentworth, the nation's largest purchaser of future payments, mounted a television ad campaign to persuade those receiving insurance settlements for their personal injuries to sign over their monthly payments in return for a lump sum, with the claims to be bundled and sold as bonds. And elderly retirees in Florida were wined and dined by entrepreneurs seeking to buy their future life insurance payoffs. Talk show host Larry King sold the settlement rights to two of his life insurance policies for $\$ 1.4$ million, but later thought better of it: As his lawyer put it, "The insured never knows if the guy barreling down the highway in a large truck coming in the opposite direction holds the insurance policy on his life. We don't know whether the owner is a Wall Street hedge fund or a Mafia don" (Pleven \& Silverman, 2007). ${ }^{10}$

The prevalence of securitization for business and other loans meant that traditional commercial banking and investment banking had become increasingly difficult to distinguish from each other. This development was ratified by the conversion to commercial banks of Goldman Sachs and Morgan Stanley, the two remaining major investment banks after the disappearance of Bear

\footnotetext{
${ }^{10}$ For a more general discussion of securitization and its effects on the financial services industry, see Davis, 2009, Chapter 4. On the emergence of the market for "viaticals," see Quinn, 2008.
}

Stearns, Lehman Brothers, and Merrill Lynch in 2008. By this point, many of the largest banks had become essentially portals to financial markets, analogous to OEM corporations. Homeowners might send their mortgage checks to Washington Mutual or Citibank, but behind the brand, the real mortgage owners turned out to be dispersed bondholders around the world. Just as corporate ownership was becoming more concentrated thanks to institutional investors, mortgage ownership was becoming more dispersed through securitization, in which thin slices of American mortgages came to be held by global institutional investors-including Norwegian pension funds. The global supply chain in finance created a situation in which American mortgages were as toxic in the portfolios of foreign investors as melamine was in the dog chow of American pet owners.

The tangled web of financial connections around the world meant that individuals' economic ties with their fellows became increasingly complex. Through my pension plan, I may own part of my neighbor's home mortgage, auto loan, and credit card debt, and be a beneficiary of his life insurance. "Social capital" has taken on a more than metaphorical meaning.

As banks and other financial institutions consolidated and merged across industry boundaries, finance became a vast meta-industry that included commercial banking, investment banking, insurance, real estate services, student loans, and others. By 2000 , roughly $40 \%$ of the profits of the S\&P500 came from financing, and companies as diverse as GE and Enron were effectively banks or hedge funds with some intermittent industrial operations (Ip, 2002).

Meanwhile, traditional commercial banks became far more concentrated, as a handful of national titans-in particular, Bank of America, JP Morgan Chase, and Citigroup-came to control an outsized proportion of the assets and deposits of the industry, turning a traditionally local business into an international one. Local and regional players were attractive targets for acquisitive banks. Charlotte-based North Carolina National Bank grew to become Bank of America through two decades of acquisitions that included 
First RepublicBank of Dallas, C\&S/Sovran of Virginia, Boatmens' Bancshares of St. Louis, Barnett Banks of Florida, San Francisco-based Bank of America, and Boston's FleetBoston, along with dozens of smaller banks across the nation. In consequence of this consolidation, most major cities in the United States ended up without a major locally based commercial bank (see Neuman et al., 2008).

Urban commercial banks had long served as the center of business elite networks through their recruitment of the CEOs of major local businesses and nonprofits to their boards. The latent effect of this practice was that corporate elites had a regular meeting place to discuss local affairs and to coordinate their philanthropic and political activities, from pitching in to support a new symphony hall or make an Olympics bid to financing the elections of Congressional candidates (Mizruchi, 1992). But a decade after the repeal of GlassSteagall, 7 of the 10 largest American cities no longer hosted a major financial institution. Meanwhile, some of the biggest banks ended up as de facto wards of the federal government.

\section{The Changing Role of the State}

$\mathrm{T}$ he practices of outsourcing that have swept the corporate and banking worlds have also spread to some of the core functions of government. After several years of attempting to "reinvent government" and reduce federal payrolls, President Clinton signed into law the Federal Activities Inventory Reform Act of 1998 (the FAIR Act). The idea was to promote government outsourcing, which would presumably bring the efficiency of private-sector organizations such as General Motors to the public sector. The act required heads of governmental agencies, including the military, to produce annual lists of functions that were eligible for outsourcing because they were not "inherently governmental," defined by the act as "a function that is so intimately related to the public interest as to require performance by Federal Government employees." 11

During the subsequent decade, government

${ }^{11}$ The text of the FAIR Act is available at http://www.whitehouse.gov/ omb/procurement/fairact.html. contracting grew staggeringly large, to the point that the government ultimately employs far more contract workers than federal employees. If the share price-driven corporation had become a "nexus of contracts," then the federal government increasingly resembled a "nexus of contractors." Annual spending on contractors doubled from roughly $\$ 200$ billion to more than $\$ 400$ billion during the years of the Bush administration, as tasks from running governmental databases to the armed protection of diplomats overseas were handed off to contractors. Indeed, the three largest remaining manufacturing employers in the United States were military contractors: Boeing, Lockheed Martin, and Northrop Grumman. (The latter two receive $85 \%$ and $90 \%$ of their revenues respectively from the U.S. government.)

The government's dependence on contractors was especially acute for the conduct of war, which many would regard as an "inherently governmental" task (Shane \& Nixon, 2007). Critics argued that employees of Blackwater and other contractors, unlike federal employees, faced divided loyalties and limited discipline in their conduct in occupied Iraq. ${ }^{12}$ But a newly "rightsized" federal workforce was evidently not up to the task of maintaining security without outside assistance. Under-Secretary of State for Management Patrick Kennedy said in 2008: "We cannot operate without private security firms in Iraq. If the contractors were removed, we would have to leave Iraq" (Risen, 2008).

In a world in which states have emulated the practices of the corporate sector, some governments have come to regard their status as sovereign as a core competence to be exploited in the global marketplace of laws. In a sense, sovereign nations have a capacity to sell products-incorporating businesses, flagging ships, establishing banks-that other types of business service vendors do not. Thus, Bermuda houses dozens of "brass plate" insurance companies, and is the virtual home of hundreds of intellectual property subsidiaries, where companies park their offshore earnings for tax purposes. The Cayman Islands hosts thousands of hedge funds, which organize as

\footnotetext{
${ }^{12}$ For more on Blackwater, see Scahill (2007).
} 
limited liability companies (LLCs) in the Caymans but operate their physical presence out of Greenwich, Connecticut, or London, England. Tuvalu, a Central Pacific island nation, has leased its national Internet domain name (.tv) to Verisign for several million dollars per year, providing the government with a substantial part of its revenue base. And for years, Liberia has been the second-largest "flag of convenience" (behind Panama), providing the laws that govern thousands of merchant ships that transport the world's physical trade in goods. Liberia's lucrative sovereignty business, in turn, is operated out of an office park in suburban Virginia.

\section{The Impact on Households}

have described several changes in the form and duration of the employment relation, the structure and ownership of corporations, the format of the financial services industry, and the nature of the state. In this section, I briefly examine the consequences of these changes for households. I suggest that as the ties that bound employees to firms were increasingly frayed, new ties were built that connected the well-being of households to financial markets. As both "investors" and "issuers," through mutual funds and securitized mortgages, households increasingly came to rely on financial markets for their prosperity and security. As a result, the financial crisis has done far more damage than it would have otherwise, and it therefore compels a rethinking of our model of social organization.

The shift in employment from stable largescale manufacturers to more ephemeral service firms changed the nature of the ties between corporations and their employees. Barley and Kunda (2006) analyzed the shift to the so-called "free agent" contract worker. The initial heady exuberance around the new Web-enabled, 401(k)-toting, self-directed contractors was followed by the subsequent letdown that accompanied the dotcom bust. The escapees from the feudal manor of the corporation ended up discovering that "independent consultant" was often simply a euphemism for "unemployed."

At the same time that workers were less tied to corporate employers, households became more tied to financial markets than ever before. All those $401(\mathrm{k})$ pension plans and retail mutual funds connected people to the broad movements of the stock market, fueling the growth of financial media and, indirectly, the expansion and contraction of the retail sector through the socalled "wealth effect." The securitization of mortgages and the ease of refinancing attuned a generation of homeowners to once-obscure numbers like LIBOR (the London Interbank Offered Rate) and riveted attention on the decisions of the Federal Reserve, which now had immediate pocketbook consequences. Alan Greenspan and James Kennedy documented that homeowners extracted about $\$ 800$ billion per year in equity during the boom years of the recent housing bubble (Greenspan \& Kennedy, 2008). Serial refinancers and those who drew on home equity lines of credit relied on continuous increases in home prices and favorable interest rates from the Fed to make up for stagnant wages. For these households, micromovements in the local real estate market might mean the difference between buying a new Pontiac and nursing the old car a few thousand more miles. The Web allowed individuals minute-byminute access to numbers such as their credit rating and the purported value of their house, through sites such as Zillow.com. And individuals were presented with increasingly novel ways of accessing funds from the capital markets-for instance, by selling their future life insurance payoffs to vendors who then bundled them with other insurance contracts and securitized them. Securitization thus remade the household budget just as it had reformatted the banking industry.

The increasing centrality of finance to everyday life also changed people's understanding of their place in society. Traditional corporate employers provided more than a job-they provided a worldview. Economist Carl Kaysen described this in the 1950s: "The whole labor force of the modern corporation is, insofar as possible, turned into a corps of lifetime employees, with great emphasis on stability of employment." Through its enveloping labor practices, "membership in the modern corporation becomes the single strongest social force shaping its career members" (Kaysen, 1957, pp. 312, 318). Peter Drucker agreed (1949, 
p. 28), claiming that the corporation "determines the individual's view of his society," in some sense providing a template for understanding how society works. The mass-production model of human organization pioneered by Henry Ford became a model for other large-scale tasks, from farming and scientific research to the D-Day invasion at Normandy. Moreover, according to Drucker, employees brought this cognitive model to bear on basic tasks of living, such as child-rearing (Drucker, 1949; cf. Kohn, 1969). Consider the Gilbreth family in Cheaper by the Dozen. Mass production had become a worldview, a way of life.

Today, a vanishingly small part of the workforce grows food or manufactures tangible objects, and long-term careers within organizations are an anomaly rather than a norm. The "society of organizations" is no longer the enveloping force it was when Drucker and Kaysen wrote. Instead, the cognitive model that holds sway for many is that of the investor. Students attending college are "investing in their human capital," while people who join a bowling league or the PTA are thereby "investing in their social capital." In a portfolio society, the organization man has been replaced by the daytrader, buying and selling various species of capital, from homes reconceived as options on future price increases, to a college education whose estimated net present value informs the choice of school and course of study, to children whose Little League games might be an apt context to cultivate potential clients.

Like corporations, banks, and states, households have discovered the joys of outsourcing. Nannies and cleaning services have existed for generations. But the same technologies that opened offshoring possibilities for corporations have also made them more readily available for all households. Services from editing vacation videos to planning a wedding can be outsourced via the Web. With Skype and a fast Internet connection, helping the kids with homework can be contracted out to low-wage (but high-skill) professionals elsewhere in the world. And online providers offer "baby branding" services, so that children can start life with a professionally vetted name that will enhance their chances at elite schools and lucrative jobs. To an increasing de- gree, parents can leave the low-value parental tasks of naming, feeding, and educating their children to global vendors, while reserving the quality time for themselves.

But what life lessons would these parents pass on to their children during their quality time? For generations, the smart advice for making one's way in the world was to go to college and take a job with a reputable company such as General Motors or U.S. Steel or Westinghouse. Drucker summarized in 1949 (ironically it is a complete inversion of what would take place just 30 or so years later): "Where only twenty years ago the bright graduate of the Harvard Business School aimed at a job with a New York Stock Exchange house, he now seeks employment with a steel, oil, or automobile company. It is not only that money has become less important than industrial capacity to produce; the old financial powers have also lost control over money and credit itself, as witness the shift in financial headquarters from Wall Street to the government agencies in Washington" (p. 27). The path to middle-class prosperity was clear enough for anyone willing to work hard and climb the corporate ladder.

Even as the stability of corporate jobs eroded, the young were advised to gain specialized education in order to participate in the "knowledge economy" at the high end of the value chain. Symbolic analysts such as accountants, computer programmers, and product designers were still paid well even if not protected by a corporate umbrella. But economist Alan Blinder suggests that in a Web-enabled world, any task that can be sent over the Internet is open to competition from suppliers around the globe, no matter what the level of skill. From completing tax forms and designing auto parts to reading X-rays and decoding the human genome, cognitive tasks are eminently offshorable. The service sector, in short, is not immune to employment volatility, and Blinder (2006) estimated that perhaps 40 million jobs in the United States were eligible for offshoring.

The news was not all hopeless for those who wanted to prepare for a job that might last for more than a few months. According to Blinder, one's job stability was enhanced by the level of 
personal touch involved. Personal fitness trainers and home health aides for retired baby boomers were not likely to be replaced by disembodied vendors on the Web. On the other hand, for those baby boomers who had the bad fortune to follow conventional wisdom prior to the Great Recession of 2008 - buy the biggest house for which you can get a mortgage, and invest your savings in a mutual fund-retirement was going to have to wait. The pathway to prosperity for the next generation was increasingly hard to discern.

\section{Moving Forward}

$\mathrm{T}$ The argument of this paper has had many moving parts, but the underlying theme is that finance shaped the transition from an industrial to a postindustrial society in the United States over the past three decades. From a society of organizations, in which corporations were essential building blocks that shaped the daily lives of their members, we evolved into a portfolio society in which household welfare was increasingly tied to the vagaries of the financial markets. The economic downturn was amplified by these ties, as consumers who had relied on increasing home and portfolio values suffered setbacks that contracted consumer spending and thus economic growth. The results reverberated around the world, from investors that had purchased securities backed by American mortgage payments to producers that relied on American consumers for their sales.

The economy will come back, but the society of organizations will not, and our research and teaching need to take this into account. Theories about organizations conceived of a world in which, as Charles Perrow put it (1991, p. 726), organizations were "the key phenomenon of our time, and thus politics, social class, economics, technology, religion, the family, and even social psychology take on the character of dependent variables." Economic mobility happened through the hiring and promotion practices of corporations, so understanding how job ladders worked could explain both class mobility and the mechanisms behind racial and gender inequality. Health care and retirement security were the province of corporate employers. Politics privi- leged those with access to resources, such as corporate executives, so examining the political contributions of major corporations such as GM or Citigroup or AIG could explain political outcomes. Urban and regional economic development was often a collective project of local corporate elites who knew each other through membership on the board of the local bank, indicating the most fruitful place to look for elite cohesion (or its absence). And individuals' understandings of their society came from their experience at work, as long years with the same employer imprinted their worldviews.

The view of organizations as the building blocks of society also informed public policy, as governmental efforts to deal with social issues often used corporations as the appropriate levers. Inequality and discrimination could be fixed through regulatory demands for equitable hiring and promotion practices among the largest corporate employers, as the Equal Employment Opportunity Commission did in the early 1970s. Workplaces could be made safer and more healthful through the Occupational Safety and Health Administration, another product of the early 1970s. Financial security in old age was strengthened by the Employee Retirement Income Security Act of 1974, which ensured that corporate employers would make good on their pension promises to their retired workers. And the Environmental Protection Agency, created in 1970, sought to create a cleaner natural environment in part through the regulation of corporate emissions.

As this paper has described, the society of organizations unwound in the United States after the early 1980s, although our conceptual model has not. For a brief period, the "ownership society" model proposed by President George W. Bush provided an alternative. Rather than rely on corporate employers for the provision of social welfare functions, Bush suggested that individuals could rely on home ownership and various individual accounts invested in the stock market to fund education, health care, and retirement. The major policy initiative of Bush's second term was an effort to partially privatize Social Security by allowing individuals to put their mandatory payroll contributions into the stock market rather 
than into the government trust fund. But the financial crisis did for the ownership society what the collapse of the Soviet Union did for state socialism. By mid-2009, the S\&P 500 was 30\% lower than it had been a decade before, and perhaps one-quarter of homeowners with mortgages owed more on their house than it was worth. Ownership of index funds and homes no longer looked like a credible source of economic security and prosperity; if anything, home ownership had left millions financially unable to move in order to pursue new jobs, had any been available.

Nostalgia is not the right response to postindustrialism. We cannot go back to a system of corporate-sponsored welfare capitalism any more than we can return to feudalism. If anything, we should be overjoyed that we have the technology to create the goods that people need with a minimal input of labor. The agenda for management scholars going forward should be to help create institutions that serve the needs for economic security and health care formerly addressed by the old system while building new opportunities. But this will require a new set of conceptual tools.

In a postindustrial economy, the applicability of several of our existing theories is called into question. Some scholars have jibed that organization theory is, to a large extent, the "science of General Motors." Consider the evidence for transaction cost economics. Our understanding of asset specificity and vertical integration is largely based on the famous case of GM's acquisition of Fisher Body in the 1920s, while the value of the multidivisional structure was demonstrated by GM's Mform (e.g., Williamson, 1975). Many studies of the make-or-buy decision also drew on evidence from American automakers prior to their divestitures of Delphi and Visteon (e.g., Walker \& Weber, 1984). But GM's declaration of bankruptcy in June 2009 also signified the bankruptcy of the corporate-industrial model that has been the basis of much of our theory and research.

Theories that rely on evidence based in manufacturing may have limited application in a service economy. Resource dependence theory, for instance, draws largely on studies of industry input-output tables in manufacturing to understand the sources of vertical integration and board in- terlocks (Pfeffer \& Salancik, 1978). The basic insights of resource dependence theory into power dynamics will have lasting value, although the sources and uses of organizational power will require a reconceptualization.

More broadly, views of organizations that take the sovereignty and boundaries of the organization for granted-e.g., those that study birth and death rates (Hannan \& Freeman, 1977)_will yield a misleading view in an economy where reconfigurable supply chains in manufacturing and service are the most critical units of analysis. As I have described it, the ontological status of many corporations is closer to that of a Web page than an organism. It is easy to create a Liberian corporation over the Internet with a credit card, and just as easy to disincorporate by failing to pay the annual fee. Should we be counting birth and death rates of such entities?

On the other hand, finance-based theories of the corporation will also not replace management-based theories. The imagery of the firm as a nexus of contracts (e.g., Jensen \& Meckling, 1976) is appealing in a world of OEM corporations, banks, and states. One might argue that finance scholars and their fellow travelers with influence in government helped make this view of the firm become true (cf. Ferraro, Pfeffer, \& Sutton, 2005). But the finance-based theory of the corporation has lost credibility in the wake of the financial crisis. The central premise of this approach is that financial markets are informationally efficient, and thus that it is appropriate for corporate governance mechanisms to guide corporations toward share price as their North Star. The merits of this view are debatable; less so are the hazards to the economy when it is broadly accepted by executives, investors, and policymakers. Indeed, some would go so far as to argue that the financial view of the corporation helped create the crisis we are in now. There is no doubt that finance and financial markets are central to what public corporations do. What is less clear is that an ownership society is a workable model for prosperity and security.

It appears that for many corporations in the United States, "creating shareholder value" will no longer be their animating purpose in the years 
to come. A fitting epitaph for this view came from Jack Welch, former CEO of GE, who said to the Financial Times in March: "On the face of it, shareholder value is the dumbest idea in the world. Shareholder value is a result, not a strategy. ... Your main constituencies are your employees, your customers and your products" (Guerrera, 2009). With the partial or complete government takeover of the country's largest bank (Citigroup), insurance company (AIG), and manufacturer (General Motors), along with mortgage behemoths (Fannie Mae, Freddie Mac) and other corporations deemed too big to fail, it is clear that a more informed sense of political economy will be essential to business scholarship in the years to come. American management scholars and MBA students are uniquely ill-informed about the operations of a mixed economy. Organizational research rooted in the United States traditionally treats governments as elements of an external "environment," to be obeyed or co-opted, or as a drag on the natural operations of markets. Examinations of the corporation going forward will require insights from scholars outside North America, where states have long played more active roles in the operations of business. This will be a welcome addition to a research tradition that has for too long taken the American case to be an exemplar to be documented and exported, rather than one path among many.

Finally, in light of this discussion, where should researchers look now? Two domains that merit greater study than they have received are the financial services industry and the global shipping industry. The financial industry has gone through a spectacular proliferation of types of organizations, with both consolidation and disaggregation occurring simultaneously. With the repeal of Glass-Steagall in 1999, the traditional barriers between investment banking, commercial banking, and insurance were breached, and a number of very large "financial supermarkets" emerged. We have seen some of the results of this experiment, but a systematic assessment is due. On the other hand, the value chain in banking has also been subject to disaggregation-consider a mortgage, which might be arranged by a self-employed broker, originated by a freestanding mortgage firm, packaged into a bond by a Wall Street bank, and purchased by a hedge fund. The industry is ripe for more detailed analyses that might help provide a postmortem on the financial crisis and insight into safeguards going forward.

The shipping industry merits greater study for another reason. The vast majority of the world's trade in physical goods is transported by tens of thousands of commercial ships that might be flagged in Panama, owned by an LLC registered in Malta, insured by Lloyd's of London, and staffed by a multinational crew of Spaniards, Croatians, Filipinos, and others (see Langewiesche, 2004). Commercial ships are both internationally diverse (often wildly so) and effectively stateless, and shipping firms are consummate purchasers of the goods of "vendor states." Examining their operations can help inform a world in which states are more business service providers than sovereign nations.

Within the economic crisis is a unique opportunity for management scholarship to provide direction. With broad sectors of the economy from finance to defense to health care on the verge of large-scale reorganization, we have a chance to inform change and apply lessons learned from other contexts, from self-organizing collective activities (e.g., open source software and Wikipedia) to social movements. Times of major economic upheaval have also been times of theoretical ferment-consider the burst of social theory at the turn of the 20th century (Adler, 2009). Perhaps we can draw on this same impulse to yield more productive contributions to efforts at reform.

\section{References}

Adler, P. S. (2009). The Oxford handbook of sociology and organization studies: Classical foundations. Oxford, U.K.: Oxford University Press.

Aeppel, T., \& Lahart, J. (2009, March 9). Lean factories find it hard to cut jobs even in a slump. Wall Street Journal, p. A1.

Applebaum, E., Bernhardt, A. D., \& Murnane, R. J. (2003). Low-wage America: How employers are reshaping opportunity in the workplace. New York: Russell Sage.

Barley, S. R., \& Kunda, G. (2006). Contracting: A new form of professional practice. Academy of Management Perspectives, 20(1), 45-66.

Bell, D. (1973). The coming of post-industrial society. New York: Basic Books. 
Berle, A. A., \& Means, G. C. (1932). The modern corporation and private property (Modern Reprint: 1991 edition). New Brunswick, NJ: Transaction.

Bernhardt, A. D., Morris, M., Handcock, M. S., \& Scott, M. A. (1999). Job instability and wages for young adult men. (Working Paper No. 99-01). State College, PA: Pennsylvania State University.

Blinder, A. S. (2006). Offshoring: The next Industrial Revolution? Foreign Affairs, 85(2), 113-128.

Bradsher, K. (1997, October 9). Ford planning to spin off lending unit. New York Times, p. D1.

Brandeis, L. D. (1914). Other people's money: And how the bankers use it. New York: Frederick A. Stokes Company.

Bucks, B. K., Kennickell, A. B., Mach, T. L., \& Moore, K. B. (2009). Changes in U.S. family finances from 2004 to 2007: Evidence from the Survey of Consumer Finances. Federal Reserve Bulletin, February, A1-A56.

Bucks, B. K., Kennickell, A. B., \& Moore, K. B. (2006). Recent changes in U.S. family finances: Evidence from the 2001 and 2004 Survey of Consumer Finances. Federal Reserve Bulletin, February, A1-A38.

Bunkley, N. (2008, November 10). Some GM retirees are in a health care squeeze. New York Times, p. B1.

Cappelli, P. (1999). The New Deal at work: Managing the market-driven workforce. Boston: Harvard Business School Press.

Cobb, J. A. (2008). The employment contract broken? The deinstitutionalization of defined benefit retirement plans. Unpublished, Ross School of Business, University of Michigan.

Cox, E. B. (1963). Trends in the distribution of stock ownership. Philadelphia: University of Pennsylvania Press.

Davis, G. F. (2008). A new finance capitalism? Mutual funds and ownership re-concentration in the United States. European Management Review, 5, 11-21.

Davis, G. F. (2009). Managed by the markets: How finance re-shaped America. Oxford, U.K.: Oxford University Press.

Davis, G. F., Diekmann, K. A., \& Tinsley, C. H. (1994). The decline and fall of the conglomerate firm in the 1980s: The deinstitutionalization of an organizational form. American Sociological Review, 59(4), 547-570.

Davis, G. F., \& Kim, E. H. (2007). Business ties and proxy voting by mutual funds. Journal of Financial Economics, $85,552-570$.

Drucker, P. F. (1949). The new society: I. Revolution by mass production. Harper's Magazine, September, 21-30.

Duca, J. V. (2001). The democratization of America's capital markets. Federal Reserve Bank of Dallas Economic and Financial Review, (Second Quarter), 10-19.

Ferraro, F., Pfeffer, J., \& Sutton, R. I. (2005). Economics language and assumptions: How theories can become self-fulfilling. Academy of Management Review, 30, $8-24$.

Fraser, S. (2005). Every man a speculator: A history of Wall Street in American life. New York: HarperCollins.

Greenspan, A., \& Kennedy, J. (2008). Sources and uses of equity extracted from homes. Oxford Review of Economic Policy, 24(1), 120-144.
Guerrera, G. (2009, March 12). Welch condemns share price focus. Financial Times. Retrieved June 26, 2009, from http://www.ft.com/cms/s/0/294ff1f2-Of27-11de-ba10$0000779 \mathrm{fd} 2 \mathrm{ac} . \mathrm{html}$.

Hacker, J. S. (2006). The great risk shift: The assault on American jobs, families, health care, and retirement-and how you can fight back. New York: Oxford University Press.

Hall, J. (2000). The roots of broadened stock ownership: Report to the Joint Economic Committee of the U.S. Congress, April 2000. Washington: U.S. Congress, Joint Economic Committee.

Hannan, M. T., \& Freeman, J. (1977). The population ecology of organizations. American Journal of Sociology, 92, 910-943.

Hansell, S. (1998, July 26). Is this the factory of the future? New York Times, section 3, p. 1.

Hilsenrath, J. E., \& Buckman, R. (2003, October 20). Factory employment is falling world-wide: Study of 20 big economies finds 22 million jobs lost; even China shows decline. Wall Street Journal, p. A2.

Ip, G. (2002, June 10). Alternative lenders buoy economy; will easy terms end hard times? Wall Street Journal, p. A1.

Jacoby, S. M. (1997). Modern manors: Welfare capitalism since the New Deal. Princeton, NJ: Princeton University Press.

Jensen, M. C., \& Meckling, W. H. (1976). Theory of the firm: Managerial behavior, agency cost and ownership structure. Journal of Financial Economics, 3, 305-360.

Kaysen, C. (1957). The social significance of the modern corporation. American Economic Review (Papers and Proceedings), 47(2), 311-319.

Kohn, M. (1969). Class and conformity: A study in values. Chicago: University of Chicago Press.

Kollmeyer, C. (2009). Explaining deindustrialization: How affluence, productivity growth, and globalization diminish manufacturing employment. American Journal of Sociology, 114, 1644-1674.

Lagace, M. (2001). Jack Welch Class Day interview-Jack Welch to HBS grads: "Don't be a jerk." Harvard Business School Working Knowledge, June 11. Retrieved June 18, 2009, from http://hbswk.hbs.edu/archive/2310.html.

Langewiesche, W. (2004). The outlaw sea: A world of freedom, chaos, and crime. New York: North Point Press.

Mizruchi, M. S. (1992). The structure of corporate political action: Interfirm relations and their consequences. Cambridge, MA: Harvard University Press.

Neuman, E. J., Davis, G. F., \& Mizruchi, M. S. (2008). Industry consolidation and network evolution in U.S. global banking, 1986-2004. Advances in Strategic Management, 25, 213-248.

O'Connell, V. (2008, September 10). Retailers reprogram workers in efficiency push. Wall Street Journal, p. A1.

Perrow, C. (1991). A society of organizations. Theory and Society, 20, 725-762.

Pfeffer, J., \& Salancik, G. R. (1978). The external control of organizations: A resource dependence perspective. New York: Harper \& Row.

Pleven, L., \& Silverman, R. E. (2007, November 26). An insurance man builds a lively business in death. Wall Street Journal, p. A1.

Quinn, S. (2008). The transformation of morals in markets: 
Death, benefits, and the exchange of life insurance policies. American Journal of Sociology, 114, 738-780.

Risen, J. (2008, May 10). Iraq contractor in shooting case makes comeback. New York Times. Retrived June 26, 2009 at http://www.nytimes.com/2008/05/10/world/ middleeast/10blackwater.html.

Rivoli, P. (2005). The travels of a T-shirt in the global economy: An economist examines the markets, power, and politics of world trade. Hoboken, NJ: John Wiley \& Sons.

Scahill, J. (2007). Blackwater: The rise of the world's most powerful mercenary army. New York: Nation Books.

Scott, W. R., \& Davis, G. F. (2007). Organizations and organizing: Rational, natural, and open systems perspectives. Upper Saddle River, NJ: Pearson Prentice Hall.

Shane, S., \& Nixon, R. (2007, February 4). In Washington, contractors take on biggest role ever. New York Times.
Retrieved June 26, 2009, at http://www.nytimes.com/ 2007/02/04/washington/04contract.html.

Sturgeon, T. J. (2002). Modular production networks: A new American model of industrial organization. Industrial and Corporate Change, 11, 451-496.

Useem, M. (1996). Investor capitalism: How money managers are changing the face of corporate America. New York: Basic Books.

Walker, G., \& Weber, D. (1984). A transaction cost approach to make-or-buy decisions. Administrative Science Quarterly, 36, 373-391.

Williamson, O. E. (1975). Markets and hierarchies: Analysis and antitrust implications. New York: Free Press.

Zuckerman, E. S. (1999). The categorical imperative: Securities analysts and the illegitimacy discount. American Journal of Sociology, 104, 1398-1438. 